УДК 349.6

DOI https:/ / doi.org/10.32837/yuv.v0i1.1571

\author{
Р. Черниш, \\ кандидат юридичних наук, доцент, \\ доцент кафедри правознавства \\ Поліського національного університету \\ Н. Бондарчук, \\ кандидат юридичних наук, доцент, \\ доцент кафедри правознавства \\ Поліського національного університету
}

\title{
ПРОБЛЕМИ ПРАВОВОГО РЕГУЛЮВАННЯ ПОВОДЖЕННЯ 3 ВІДХОДАМИ ЗА ЗАКОНОДАВСТВОМ УКРАЇНИ
}

В умовах сьогодення в Україні гостро постає питання несанкціонованого (у тому числі й з перевищенням допустимих нормативів) видалення відходів і речовин, що забруднюють. Зазначене, зважаючи на недостатність контролю й адміністративно-профілактичного впливу держави, призводить до погіршення екологічної ситуації та, як наслідок, завдає шкоди життю та здоров’ю громадян. Разом із вищевказаним окреслене проблемне питання на фоні ведення бойових дій на сході України, скрутного економічного становища в державі тощо може призвести як до виникнення джерел соціальної напруги, так і формування іміджу України на міжнародній арені як держави, у якій нівелюються передбачені законом права та загалом набув поширення правовий нігілізм [5].

Система управління відходами в Україні характеризується такими тенденціями: 1) накопичення відходів відбувається як у промисловому, так i побутовому секторі, що негативно впливає на стан довкілля й здоров'я людей; 2) утилізація та видалення небезпечних відходів здійснюється неналежним чином; 3) розміщення побутових відходів робиться без урахування можливих небезпечних наслідків; 4) рівень використання відходів як вторинної сировини $є$ неналежним унаслідок недосконалості організаційно-економічних засад залучення їх у виробництво; 5) впроваджені економічні інструменти у сфері поводження з відходами є неефективними [4].

Відповідно до ст. 361 Угоди про асоціацію між Україною та Європейським Союзом передбачено співробітництво, спрямоване на вирішення регіональних і глобальних проблем навколишнього середовища, зокрема у сфері управління відходами й ресурсами [2]. Відтак Україна зобов'язана імплементувати Директиву № 2008/98/ЄС про відходи та скасування деяких Директив, Директиву № 2006/21/ЄС про управління відходами видобувної промисловості та внесення змін і доповнень до Директиви № 2004/35/ ЄС і Директиву № $1999 / 31 /$ ЄС про захоронення відходів зі змінами й доповненнями, внесеними Регламентом (EC) № $1882 / 2003$.

У 2017 р. була прийнята Національна стратегія управління відходами в Україні до 2030 р. Стратегія передбачає удосконалення нормативно-правової бази з питань організації роздільного збирання усіх відходів та їх перероблення і утилізації. Слід зауважити, що чинні нормативні документи, які регулюють питання поводження з відходами, потребують суттєвого вдосконалення, а затримка з їх 
поліпшенням створюватиме передумови до подальшого поширення порушень у цій сфері.

Відповідно до Закону України «Про відходи» відходами є будь-які речовини, матеріали й предмети, що утворилися в процесі виробництва чи споживання, а також товари (продукція), що повністю або частково втратили свої споживчі властивості й не мають подальшого використання за місцем їх утворення чи виявлення і яких їхній власник позбувається, має намір або повинен позбутися шляхом утилізації чи видалення [3].

Враховуючи природні й економічні фактори, основну складову частину в загальній масі відходів, що утворюються в Житомирській області, становлять тверді побутові відходи та виробничі відходи 4 класу небезпеки, які в основному видаляються на полігони, сміттєзвалища, накопичувачі тощо. Станом на 1 вересня 2019 р. в обласному реєстрі місць видалення відходів зазначено 6 полігонів та 845 сміттезвалищ. Протягом 2018 р. підприємствами й суб'єктами господарювання регіону утворено 486,1 тис. т відходів. По містах обласного значення та районах загальна кількість накопичених відходів I-IV класів склала 5,5 млн т, в основному це відходи сільського та лісового господарств, переробної промисловості, відходи видобування корисних копалин, каменеобробної промисловості. Відходи I-III класу небезпеки склали 1,1 тис. т.

Основна частина утворених відходів - люмінесцентні лампи, батареї свинцеві зіпсовані або відпрацьовані, масла й мастила моторні трансмісійні зіпсовані або відпрацьовані, матеріали фільтрувальні зіпсовані, відпрацьовані чи забруднені, матеріали обтиральні зіпсовані, відпрацьовані чи забруднені, шини зіпсовані перед початком експлуатації, відпрацьовані, пошкоджені чи забруднені під час експлуатації, залишки очищення резервуарів, що містять нафтопродукти, суміш речовин мастильних та масел 3 вод стічних, осад промислових стоків, абсорбенти зіпсовані, відпрацьовані чи забруднені тощо.

Незважаючи на часткове вирішення питання утилізації непридатних пестицидів й агрохімікатів у попередні роки вказане залишається однією з гострих екологічних проблем області.

Разом із тим станом на 1 вересня 2019 р. на території області залишалося 392,18 т непридатних до використання хімічних засобів захисту рослин, які підлягають знешкодженню. Найбільший обсяг непридатних пестицидів накопичено в Овруцькому, Коростенському, Олевському, Лугинському, Народицькому, Новоград-Волинському й Бердичівському районах. Умови зберігання більшості вказаних хімічних засобів захисту рослин не відповідають чинним екологічним і санітарним нормам. Незадовільні умови зберігання призводять до того, що токсичні пестициди потрапляють до навколишнього середовища, в тому числі до водних джерел і повітря, в результаті чого виникає ризик отруєння для людей, флори й фауни. На серпень 2019 р. в Україні суб'єкти господарювання, які мають ліцензію на проведення операцій у сфері поводження з небезпечними відходами (збирання, перевезення, зберігання, оброблення, утилізація), у тому числі й не придатних до використання пестицидів, відсутні. Зазначене може свідчити про неконтрольований їх обіг чи видалення на території області.

Актуальним для області залишається видалення відходів тваринного походження. За даними Головного управління Держпродспоживслужби в Житомирській області, на території регіону нараховується 44 худобомогильники й 7 біотермічних ям. Зазначені місця поховання трупів тварин взято на облік в районних управліннях Держпродспоживслужби 3 оформленням ветеринарно-санітарних карток. Згідно зі статистичними даними за 2018 р. на територіях худобомогильників було захоронено лише 727 кг відходів тваринного походження, хоча обсяги переробленої сировини в десятки й сотні 
разів перевищують вказаний показник, що може свідчити про протиправне видалення таких відходів.

Аналіз правозастосовної практики у вказаній сфері свідчить, що, незважаючи на масовість порушень під час утилізації відходів на території області та й держави загалом, нормативна база, що регулює порядок поводження з відходами, а також нарахування шкоди / збитків в результаті протиправних дій у сфері поводження з відходами, залишається недосконалою. Зазначене призводить до низької ефективності спеціалізованих державних органів у сфері екології (Держекоінспекціі) і не забезпечує адекватний вплив на зменшення негативного впливу викидів у навколишнє середовище.

Державною екологічною інспекцією Поліського округу на території Житомирської області за шкоду, обумовлену забрудненням і засміченням земельних ресурсів через порушення природоохоронного законодавства, протягом 2018 р. нараховано для відшкодування порушниками всього 58 тис. грн, 3 яких сплачено до бюджету 29,3 тис. грн. Протягом 2019 р. нараховано 30,3 тис. грн, 3 яких станом на 7 жовтня 2019 р. не сплачено жодної копійки, що не відповідає масштабам правопорушень у вказаній сфері та заподіяній шкоді.

Враховуючи викладене, $€$ необхідність поліпшення нормативної бази щодо поводження з відходами в частині:

- затвердження Кабінетом Міністрів України порядку видачі дозволу на здійснення операцій у сфері поводження 3 відходами, який відсутній з 2014 р., а також порядку й правил страхування цивільної відповідальності суб'єктів господарювання за шкоду, яку може бути заподіяно довкіллю або здоров'ю людей під час зберігання й застосування пестицидів і агрохімікатів;

- розроблення та затвердження відомчого порядку поводження з відходами, який би регламентував питання зберігання, розміщення, утилізації й видалення відходів (попередній чинний порядок, передбачений ДСанПіН 2.2.7.029-99 «Гігієнічні вимоги щодо поводження 3 промисловими відходами та визначення їх класу небезпеки для здоров'я населення», скасований у 2014 р.);

- розроблення й затвердження відомчого порядку визначення класів небезпеки відходів, а також ступеня їхної небезпечності для навколишнього середовища.

- крім того, враховуючи низький рівень відповідальності органів державної влади та місцевого самоврядування у сфері поводження з відходами, вважається за доцільне передбачити Законами України їхні обов'язки, оскільки в законодавстві передбачено лише повноваження; відсутність обов'язків дає можливість органам виконавчої влади та місцевого самоврядування не виконувати норми законодавства про відходи, в тому числі довгий час не проводити ліквідацію несанкціонованих звалищ відходів тощо;

- окремого поліпшення потребує «Методика визначення розмірів шкоди, зумовленої забрудненням і засміченням земельних ресурсів через порушення природоохоронного законодавства», затверджена Наказом Міністерства охорони навколишнього природного середовища України від 4 квітня 2007 р. № 149 та зареєстрована в Міністерстві юстиції України 25 квітня 2007 р. за № 422/13689 (далі - «Методика») [1], a саме:

- до п. 1.2 «Методики», яким встановлюється порядок розрахунку розмірів відшкодування шкоди суб'єктами господарювання й фізичними особами в процесі їхньої протиправної діяльності у сфері поводження 3 відходами, необхідно включити органи виконавчої влади й органи місцевого самоврядування, 3 вини або бездіяльності яких утворюються несанкціоновані й неконтрольовані звалища побутових і промислових відходів, що призводить до засмічення й забруднення земель; 
- $з$ п. 3.2 «Методики», яким землі вважаються засміченими, якщо на відкритому грунті наявні сторонні предмети й матеріали, сміття без відповідних дозволів, що призвело або може призвести до забруднення навколишнього природного середовища, необхідно виключити текст «що призвело або може призвести до забруднення навколишнього природного середовища», оскільки суди під час розгляду справ про відшкодування шкоди, обумовленої засміченням земельних ділянок, відмовляють у задоволенні позовів у зв'язку з тим, що неможливо довести забруднення навколишнього природного середовища внаслідок засмічення земельної ділянки;

- виключити 3 підп. 3.5.1 «Методики» термін «об'єм відходів», оскільки в ході перевірки неможливо інструментально точно виміряти товщу засмічення / забруднення, що в подальшому зводить нанівець судову перспективу доказування сум збитків тощо («об’єм відходів» (куб. м), що спричинили засмічення, встановлюють за об’ємними характеристиками цього засмічення через добуток площі засмічення земельної ділянки й товщини шару цих відходів; товщину шару відходів ділянки визначають вимірюванням);

- виключити 3 пп. 4.2, 4.7, 4.7.1, 4.7.2, 5.2, 5.6, 5.6.1, 5.6.2 «Методики» поняття «нормативна грошова оцінка земельної ділянки», оскільки в багатьох населених пунктах і за межами всіх населених пунктів Житомирської області нормативна грошова оцінка не визначена, що створює колосальний дисбаланс у сумах нарахування збитків на землях, щодо яких проведено нормативну грошову оцінку і щодо яких такого оцінювання не проведено;

- змінити окремі коефіцієнти формул 1 і 4 «Методики», на основі яких розраховується шкода (збитки), обумовлена забрудненням земель, щоб результат інструментально-лабораторних вимірювань прямо впливав на розмір шкоди, обумовленої забрудненням земельної ділянки.
Довідково: відповідно до п. 4.6 «Методики» розмір шкоди від забруднення земель визначається за формулою (1): $\mathrm{P}_{\text {ш }}=\mathrm{A} \times \Gamma_{\text {Оз }} \times \Pi_{\text {д }} \times \mathrm{K}_{3} \times \mathrm{K}_{\mathrm{H}} \times \mathrm{K}_{\mathrm{EГ}}$,

де $\mathrm{K}_{3 .}$ - коефіцієнт забруднення земельної ділянки, що характеризує кількість речовини, що забруднює, в об'ємі забрудненої землі залежно від глибини просочування.

Згідно з підп. 4.8.2 «Методики», якщо вміст речовини, що забруднює, встановлювався за результатами інструментально-лабораторного контролю, коефіцієнт забруднення земельної ділянки $\left(\mathrm{K}_{3}\right)$ визначається за формулою (4):

$$
\mathrm{K}_{3}=\mathrm{C}_{3 \mathrm{P}} \times \Gamma_{\Pi} / \mathrm{T}_{\text {зш }} \times \mathrm{I}_{\Pi} \times \mathrm{K}_{\mathrm{PO} 3} .
$$

Так, у разі визначення коефіцієнту забруднення земельної ділянки за формулою (4) «Методики» з будь-яким значенням (до 100000 мг/кг) $\mathrm{C}_{3 \mathrm{p}}$ концентрація (масова частка) речовини, що забруднює, за результатами інструментально-лабораторного контролю $\left(\mathrm{K}_{3}\right)$ буде менше 1,0 або рівно 1,0.

Згідно з підп. 4.8.4 «Методики» за розрахованого значення $\mathrm{K}_{3}<1$ його значення приймається рівним 1,0 .

У разі множення будь-якого числа на 1 (одиницю) в добутку дістаємо те саме число;

- збільшити у формулах «Методики» значення коефіцієнта еколого-господарського значення земель сільськогосподарського призначення й земель лісового фонду $\left(\mathrm{K}_{\mathrm{E \Gamma}}\right)$, що забезпечило б адекватні кінцеві значення розрахунків шкоди, обумовленої забрудненням земельної ділянки, залежно від ступеня протиправної дії.

Довідково: згідно з п. п. 4.10 та 5.8 «Методики» значення коефіцієнта еколого-господарського значення земель $\left(\mathrm{K}_{\mathrm{Eг}}\right)$ приймається відповідно до категорії земель, що зазнали забруднення, або іхнього статусу як таких, що підлягають особливій охороні згідно з додатком 2.

Своєю чергою відповідно до додатка 2 «Методики», коефіцієнт еколого-господарського значення землі сільськогосподарського призначення й земель лісового фонду становить 1,0. 
У разі множення будь-якого числа на 1 (одиницю) в добутку дістаємо те саме число.

Підсумовуючи вищевикладене, можливо дійти висновків про те, що неналежне поводження 3 відходами та їх накопичення вкрай негативно впливає на стан навколишнього природного середовища й здоров'я людей в Україні. Нормативно-правове регулювання поводження 3 відходами, що, зокрема, призводить до низької ефективності спеціалізованих державних органів у сфері екології, не можна вважати достатнім. В умовах сьогодення вдосконалення законодавства у сфері управління відходами є однією з необхідних умов інтеграції України до європейської спільноти. Відтак національне законодавство в указаній сфері потребує суттєвих змін і доповнень.

Стаття присвячена проблемам правового регулювання поводження з відходами за законодавством України. Ї̈ актуальність обумовлена тим, що сучасна система управління відходами в Україні характеризується їх накопиченням як у промисловому, так $i$ в побутовому секторі, розміщенням без урахування можливих небезпечних наслідків, неналежним рівнем використання відходів як вторинної сировини, неефективністю впроваджених економічних інструментів у сфері поводження з останніми тощо. Що своєю чергою вкрай негативно впливае на стан навколишнього природного середовища $i$ здоров'я людей.

Аналіз правозастосовної практики в указаній сфері свідчить, що незважаючи на масовість порушень, які мають місце в процесі утилізації відходів, нормативна база, що регулює порядок поводження з ними, а також нарахування икоди/збитків в результаті протиправних дій у сфері поводження з відходами, $є$ недосконалою. Зазначене також призводить до низької ефективності спеціалізованих державних органів у сфері екології й не забезпечує адекватного впливу на зменшення негативних наслідків викидів у навколишне середовище.

Відповідно, національне законодавство в указаній сфері потребує суттевих змін і доповнень. Зокрема, необхідним є затвердження порядку надання дозволу на здійснення операцій у сфері поводження з відходами, розроблення й затвердження відомчого порядку поводження з відходами, який регламентував би питання зберігання, розміщення, утилізації й видалення відходів, розроблення й затвердження відомчого порядку визначення класів небезпеки відходів, а також ступеня їхньої небезпечності для навколишнього середовища. Крім того, потрібно внесення сутmєвих змін до Методики визначення розмірів шкоди, зумовленої забрудненням $і$ засміченням земельних ресурсів через порушення природоохоронного законодавства.

Ключові слова: відходи, нормативно-правове регулювання, управління, утилізація, збитки.

Chernysh R., Bondarchuk N. Problems of legal regulation of waste management under the legislation of Ukraine

The article is devoted to the problems of legal regulation of waste management under the legislation of Ukraine. Its relevance is due to the fact that nowadays, the waste management system in Ukraine is characterized by their accumulation in both the industrial and household sectors, disposal without taking into account the possible dangerous consequences, improper use of waste as secondary raw materials, inefficiency of implemented economic instruments in the sphere of recent economic instruments. Which in turn has a very negative impact on the environment and human health.

An analysis of the law enforcement practice in this area shows that, despite 


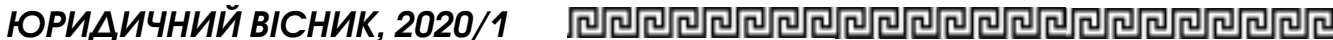

the mass of violations that occur in the process of waste management, the regulatory framework governing their treatment and the calculation of damage / damage resulting from illegal activities in the field of waste management are imperfect. This also leads to low efficiency of specialized state bodies in the field of ecology and does not provide adequate impact on reducing the negative impact of emissions into the environment.

Accordingly, national legislation in this area requires substantial changes and additions. In particular, it is necessary to approve the procedure for issuing a permit for operations in the field of waste management, to develop and approve a departmental order of waste management, which would regulate the issues of storage, storage, disposal and disposal of waste, to develop and approve a departmental order of determining the hazard classes of waste, and also the degree of their danger to the environment. In addition, it is necessary to make significant changes to the methodology for determining the amount of damage caused by pollution and contamination of land resources due to violation of environmental legislation.

Key words: waste, regulation, management, recycling, losses.

\section{Література}

1. Методика визначення розмірів шкоди, зумовленої забрудненням $i$ засміченням земельних ресурсів через порушення природоохоронного законодавства» : затверджена Наказом Міністерства охорони навколишнього природного середовища України від 4 квітня 2007 р. № 149. URL: https: / / zakon.rada.gov.ua / laws / show / z0285-98 (дата звернення: 12.03.2020).

2. Національна стратегія управління відходами в Україні до 2030 р. : затверджена Розпорядженням Кабінету Міністрів України від 8 листопада 2017 p. № 820-p. URL: https: / / zakon.rada.gov.ua/ laws / show /820-2017-\%D1\%80 (dama звернення: 28.02.2020).

3. Про відходи : Закон України від 5 березня 1998 р. № $187 / 98-B P$. URL: https: / / zakon.rada.gov.ua/laws / show $/ 187 / 98-\%$ D0\% B2\%D1\%80 (Jama звернення: 08.03.2020).

4. Угода про асоиіацію між Украйною, з однієї сторони, та Європейським Союзом, Європейським співтовариством з атомної енергії $i$ їхніми державами-иленами, з іншої сторони : Угоду ратифіковано із заявою Законом № 1678-VII від 16 вересня 2014 p. URL: https: / / zakon.rada.gov.ua/ laws /show/984_011 (дата звернення: 11.01.2020).

5. Черниш Р.Ф., Назарчук Б.Ю. «Патентний тролінг» як передумова до загострення суспільно-політичної ситуації в державі та формування негативного іміджу України на міжнародній арені (за прикладом Житомирської області) / Р. Черниш. Часопис київського університету права. URL: http: / / kul.kiev.ua/doc/CHAS16_2.pdf (дата звернення: 25.03.2020). 